\title{
The Bacteriological Status of Five Selected Street Vended Cooked Foods in Calabar, Nigeria
}

\author{
Mbah .M ., Ogban .G. I., Konlack.G.D., USEH. M. F., Asuquo. A .E \\ Department of Medical Laboratory Science, Faculty of Allied Medical Science, University of Calabar, Nigeria.
}

\begin{abstract}
Street vended cooked foods, an integral part of urban economy in the development world, have been implicated in the transmission food borne diseases. To assess the bacteriologic quality of street-vended foods, 260 samples of ready to eat foods such as rice (100), Garri (88), Yam (20) Beans (36) and fufu (16) were collected over a period of one month from 78 street vendors encountered in Watt market, Marian market and University of Calaba, all in Cross River State, Nigeriar. Inspection of food preparation and vending areas was also carried out with aim of determining their hygienic conditions. Standard methods were used to determine aerobic plate count (APC) as well as spore counts in the food samples. Significant colonies isolated from the highest dilution showing growth of all samples were characterized to genus level. About 132 isolates belonging to 5 genus recovered from aerobic plates count of 260 food samples. These included coliform bacteria 44 (33.4\%) Staphylococcus. aureus 36 (27.3\%), Bacillus cereus 28 (21.2\%), Pseudomonas aeruginosa 16 (12.1\%) and Proteus mirabelis $8(6.0 \%)$. There was no significant difference $(P>0.05)$ in the occurrences of Bacterial agents by sample location. The predominance of coliform bacteria as contaminants in street vended foods in this study implies that poor hygiene may be a significant problem during preparation and vending of such foods. The contamination of food is preventable, although prevention requires a number of control efforts along the food chain from production to consumption. Close observation through personal inspection of food vending areas, methods of food storage and other food vending facilities confirmed that food hygiene was highly compromised among the food vendors.
\end{abstract}

Key Words: Street vended cooked foods, Bacteriological status, Calabar, Nigeria

\section{Introduction}

Street vended foods are ready - to - eat foods prepared and hawked / sold by vendors especially in streets, markets and other similar public places (1).

Infectious food-borne diseases are of major public health importance worldwide and may not be eliminated in the foreseeable future(2). Microorganisms are abundant and ubiquitous in nature and their role as causative agents of food borne illnesses was recognized way back in the $19^{\text {th }}$ century. It was discovered by the end of the $19^{\text {th }}$ century that microorganisms were responsible for a variety of food borne diseases (1), Microbial contamination of foods present challenges that are different from those posed by toxins and physical hazards to the scientific, public health, and food authority communities in all countries(1).

It is estimated that between 24 and 81 million cases of food borne diarrhea diseases occur each year in the United States, costing between $\$ 5$ million and $\$ 17$ billion in medical care and loss of productivity (2). Food suppliers or sellers bring the public into intimate contact with a variety of microorganisms that are present in the various food production and processing environment from around the world (3). First, microorganisms are complex and ever changing. They can evolve quickly by exchanging genetic materials toacquirepropertiesthat help them colonize new niches or create new diseases. Secondly many microorganisms are able to grow and multiply on foods by using it as an energy source.Thirdly, the potential of food to transmit infections is high because food safety can be compromised at many points between the farm,or catch and table (3). Food borne diseases may result from unhygienic practices during food production, preparation and distribution. In particular, feacal contamination, as occurs in abattoir, is a means of transmitting infectious diseases (4).Food safety is a complex matter that depends on a number of interrelated environmental and socio economic factors (3). The food producers, hawkers and consumers respectively bear the responsibility of raising, transporting, processing and consuming prepared food that present the maximum level of risk from food borne hazard including pathogenic micro-organisms, that is practical and achievable within the limit of current technology (3). Because even small numbers of infectious organisms may cause disease as a result of poor personal hygiene, improperly cleaned utensils, storage and preparation areas should not be associated with ready-to-eat foods. A previous study by Notermans (5) showed that the number of microorganisms present in food at the time of consumption can be determined. Factors such as the type of host individual, strain of the organisms, and the type of food in which the organisms occurs can have a considerable effect on stability to infection. Thus the probability of infection varies from pathogen to pathogen, from one to another and among different groups of 
people in the community (6). According to Fabio.JacKson (7), food production is the largest industrial sector concerned with consumer issues: it employs $10 \%$ of the world population. Because we need food to survive, someone must be responsible for the safety of the food. The aims and objectives of the present study was to analyse the bacteriological status of some selected street vended foods in Calabar, as well as examined the probable sources or risk factors that contaminates street-vended foods

\section{Materials And Methods}

The study was carried out in Calabar metropolis ,the capital of Cross River State in Nigeria. Calabar is situated between latitude $04^{\circ} 57^{\prime} 10^{\prime \prime}$ north and longitude $08^{\circ} 19^{\prime} 10^{\prime \prime}$ east . The study area were the two major markets located in the city namely the Watt, Marian market and the food canteens in the University of Calabar. The project proposal was approved by the ethical committee of the Cross River Ministry of Health, Calabar. All the participants were informed about the objectives of the Study and were asked to sign an informed consent document.

Collection of food samples

260 food samples such as rice, Garri, yam, beans and fufu were collected from 78 ready to eat food vendors selected randomly from Watt market, Unical canteens and Marian market, for over a period of one month. The subjects from whom the food samples were collected included 9 males and 69 female vendors. The food samples were collected from various selling points from $3 \mathrm{pm}-5 \mathrm{pm}$ each day.

About 1 to $2 \mathrm{~g}$ of food was picked from 5 different areas of a plate of food sold to the investigators (one gram in the middle, one gram each at four different spots using sterile wire loop). The samples from different spots were mixed together in a clean dry sterile universal container and covered before conveying to the laboratory in coolers for analysis.

\section{Preparation and culture of food Samples}

All food samples were homogenized into sterile containers .For food samples such rice ,plantain,yam,beans and fufu, it was assumed that the contamination would have been on the surface (Bejamin,1995). Such samples were immerse into $5 \mathrm{ml}$ of sterile water and shaken for one minute before preparing a working solution of $1 / 10$. Two grams of each of the food sample was added to $18 \mathrm{ml}$ of sterile water to make a $1 / 10$ dilution , and serial dilution $(1 / 2,1 / 4,1 / 8)$ was prepared as described by John et al (8). The dilutions were inoculated onto blood agar and maconkey plates and allowed to dry before incubating in an inverted position for 24 to 48 hours at $35^{\circ} \mathrm{c}$.

\section{Examination of food samples}

The isolates were counted from the highest dilution (1/2). Only plates with bacteria count from the highest dilution between 25 colonies and above were considered significant to cause disease (10). These isolates were sub cultured to obtain pure culture using streak plate method as described by John et al (8) and were incubated ordinarily at $37^{\circ} \mathrm{c}$. The isolates were identified using standard bacteriological techniques (9).

Differential media such as MacConkey agar, Kliger iron agar and Mannitol salt agar and selective media such as Xylose lysine deoxycholate agar ,Deoxycholate citrate agar and were used to distinguish between colonies of the desired organism from other colonies growing on the sample plate.

\section{Results}

Table 1 shows the distribution of food samples by location and their rates of contamination. The food samples were classified as heavily contaminated (greater than 25 bacterial colonies in $1 / 2$ dilution), moderately contaminated (less than 25 bacterial colonies) and not contaminated (No bacterial colonies). Microbial contamination of food was comparable in all sample location although Watt market had a slightly higher level of contamination than other locations. Of the 260 samples collected $114(43.8 \%)$ were collected from Watt market, 108 (41.6\%) from Unical canteens and 38 (14.6\%) from Marian market. A total of 132 (50.7\%) of the 260 food samples was contaminated. There was a statistically significant difference in the occurrences of bacteriologic agents by sample location $\left(X^{2}=0.67, \mathrm{p}<0.05\right)$.

The pattern of occurrence of bacteriological agents in food samples by sample location is displayed on Table 2. Of the 132 heavily contaminated samples 101 (38.7\%) were contaminated by one bacterial type while $31(12.1 \%)$ had more than one bacterial type.

The distribution of bacteria in positive samples is presented in Table 4. Gram-negative bacteria constituted (51.8\%) of total isolates while Gram-positive bacteria accounted for $(48.5 \%)$. 
The Bacteriological Status Of Five Selected Street Vended Cooked Foods In Calabar, Nigeria

Out of 260 food samples collected, 132 (50.7\%) yielded significant bacterial growth while 128 (49.3\%) yielded insignificant or no bacterial growth. The predominant organisms isolated were coliform bacteria 44 (33.4\%) S. aureus 36 (27.3\%), Bacillus spp 28 (21.2\%). P. aeruginosa 16 (12.1\%) and proteus spp 8 (6.0\%) (Table 4).

The distribution of bacteria isolates by type of foods is shown in Table 3. The results reveals that four out of five types of bacteria isolates in this study were found in rice and beans followed by garri where three of the isolates were identified. In fufu and yam only one bacterial organism was isolated.

In about 59 of the 78 vending areas, the surroundings and floors appeared clean but attracted few flies . In contrast about 19 (24\%) maintained very low hygienic standards with resultant attraction of flies to the vending area. Cultures of water used for final rinsing of plates prior to serving food yielded significant numbers of bacteria. The personal hygiene of vendors which included the state of dresses, finger nails etc also revealed major deficiencies. Water used for washing plates and cups was used for long periods without replacement. $87.5 \%$ of consumers were not concerned about tableware and utensils used to serve food and $64.1 \%$ of the food sold was processed else where and then taken to the vending locations therefore inspecting the vending locations did not show the real conditions and hygienic problem as it depends on the hygienic conditions at the food processing venue and food transportation facilities.

Table 1

OCCURRENCE OF BACTERIOLOGICAL AGENTS BY SAMPLE LOCATION

\begin{tabular}{lccrc}
\hline LOCATION & $\begin{array}{r}\text { TOTAL NO.OF } \\
\text { SIGNIFICANT }\end{array}$ & $\begin{array}{c}\text { NO }(\%) \text { OF FOODNO(\%) OF FOOD SAMPLES } \\
\text { SAMPLES WITH COLLECTED }\end{array}$ & SAMPLE WITH \\
& \multicolumn{3}{c}{$\begin{array}{c}\text { INSIGNIFICANT GROWTH } \\
\text { BACTERIAL GROWTH }\end{array}$} \\
\hline Watt Market & $114(43)$ & $60(23.0)$ & $56(21.5)$ & $54(20.8)$ \\
Unical canteens & $108(41.6)$ & $16(6,2)$ & $52(20)$ \\
Marian Market & $38(14.6)$ & $\mathbf{1 3 2}(\mathbf{5 0 . 7})$ & $22(8.5)$ \\
Total & $\mathbf{2 6 0 ( 1 0 0 )}$ & $\mathbf{1 2 8}(\mathbf{4 9 . 3})$ & \\
\hline
\end{tabular}

Table 2

PATTERN OF OCCURRENCES OF BACTERIAL AGENTS IN FOOD SAMPLES BY LOCATION

\begin{tabular}{llll}
\hline location & No. of samples collected & $\begin{array}{l}\text { No. }(\%) \\
\text { with of food sample } \\
\text { growth }\end{array}$ & $\begin{array}{l}\text { No.(\%) of food samples } \\
\text { single }\end{array}$ \\
bacterial $\begin{array}{l}\text { with mixed significant } \\
\text { bacterial growth }\end{array}$ \\
\hline Unical Canteen & 108 & $44(16.9)$ & $12(4.7)$ \\
Watt Market & 114 & $45(17.2)$ & $15(5.8)$ \\
Marian Market & 38 & $12(4.6)$ & $4(1.6)$ \\
Total & $\mathbf{2 6 0}$ & $\mathbf{1 0 1 ( 3 8 . 7 )}$ & $\mathbf{3 1 ( 1 2 . 1 )}$ \\
\hline
\end{tabular}

Table 3

DISTRIBUTION OF BACTERIAL ISOLATES BY TYPE OF FOOD SAMPLES

\begin{tabular}{lcccccc}
\hline Samples & \multicolumn{2}{c}{ Fufu(\%) } & \multicolumn{5}{c}{ garri(\%) rice(\%) } & \multicolumn{3}{c}{ Beans(\%) Yam(\%) Total(\%) } \\
& $\mathrm{n}=16$ & $\mathrm{n}=88$ & $\mathrm{n}=100$ & $\mathrm{n}=36$ & $\mathrm{n}=20$ & $\mathrm{n}=260$ \\
\hline S.aureus & $12(75)$ & - & $16(16)$ & $8(22.2)$ & - & $36(13.8)$ \\
Bacillus spp & - & $8(9)$ & $8(8)$ & 12() & - & $28(10.7)$ \\
P. aeruginosa & - & - & - & $4(11.1)$ & - & $4(1.5)$ \\
Proteus spp & - & $4(4.5)$ & $4(4$ & - & - & $8(3.1)$ \\
Coliform bacteria - & $16(18.2)$ & $16(16)$ & $8(22.2)$ & $4(20)$ & $44(16.9)$ \\
Total & $\mathbf{1 2}(\mathbf{7 5})$ & $\mathbf{2 8 ( 3 1 . 9 )}$ & $\mathbf{4 4 ( 4 4 )}$ & $\mathbf{3 2}(\mathbf{8 8 . 9})$ & $\mathbf{4}(\mathbf{2 0})$ & $\mathbf{1 2 0}(\mathbf{4 6 . 2 )}$
\end{tabular}

- denotes that no bacterial agent was isolated 
The Bacteriological Status Of Five Selected Street Vended Cooked Foods In Calabar, Nigeria

\section{Table 4}

BACTERIAL DISTRIBUTION IN POSITIVE SAMPLES

ORGANISMS NO $(\%)$ OF ISOLATES
GRAM- POSITIVE

S. aureus
Bacillus

Subtotal $36(27.3)$

$28(21.2)$

$64(48.5)$

GRAM NEGATIVES

\begin{tabular}{lc}
\hline P. aeruginosa & \\
Proteus spp & $8(6.0)$ \\
Coliform Bacteria & $44(33.4)$ \\
Subtotal & $\mathbf{6 8}(\mathbf{5 1 . 5 )}$ \\
Grand Total & $\mathbf{1 3 2}(\mathbf{1 0 0})$ \\
\hline
\end{tabular}

\section{Discussion}

Street food vendors are often the most affordable source of ready made meals for urban workers near their places of work(WHO,1992). Street foods are popular in Calabar city and is more convenient for labour workers, civil servants and students(11). Five major foods consumed in Calabar were investigated. Among these foods, the most heavily contaminated was beans with $89 \%$ of samples contaminated by at least 4 bacterial isolates. This was followed by fufu with $75 \%$ colonized by S. aureus, $44 \%$ of rice was contaminated, yam had the least level of colonization with only $4(20 \%)$ of the 20 samples yielding significant bacteria growth. The $51 \%$ rate of contamination of street vended foods in this study is comparable with the $56 \%$ reported by Sobel et al (12). The study reveals that $132(50.7 \%)$ food samples yielded significant bacterial growth Table 1 . This is comparable with $56 \%$ rate of significant bacterial isolates reported by Sobel et al in Guatemala(12). The unhygienic condition of the vending areas as observed in this study may have contributed to the contamination of street vended cooked foods. This may explain why the vending areas with poor hygienic conditions were more contaminated than those with good hygienic conditions. According to Quick et al (13), the use of clean water to wash utensil, which is replaced from time to time reduce bacterial contamination. Coliform bacteria were the most prevalent organisms in this study constituting 44 (33.4\%) of the isolates. This was followed by S. aureus 36 (27.3\%), Bacillus spp 28 (21.2\%), P. aeruginosa 16 (12.1\%) and proteus spp 8 (6.0\%). Bacillus spp and Micrococcaceae were the most frequently isolated agents in Johannesburg, South Africa. The highest frequency of occurrences of coliform-like bacteria in this study may have originated from feacal contamination through unwashed hands, and long and dirty fingernails maintained by some of the vendors.

The microbial load in the food investigated in the study may not be unconnected with the poor hygienic condition observed in some of the food vending areas in this study. Such conditions include: Improper garbage disposal, Proliferation of house flies in the vending area, dirty table wares and vendors' dressing and some food kept uncovered

This indicates that the sources of bacterial contamination of foods in both studies differ While the prevalence of coliforms indicates feacal contamination, S. aureus being a normal flora of the skin of human may have originated from those sources. The high incidence of Bacillus spp in this study has important health implications. Although the species of Bacillus was not determined ,B.cereus, a normal inhabitant of the soil is a common contaminant of a variety of foods and its spore is important in food borne illness. The hydrophobic structure of the spore enable it to identify with several types of surfaces and it is not easily removed by cleaning even with disinfectant.

A total assessment of the risk factors associated with street vended foods was not possible as a condition under which food was prepared could not be determined. There was no statistically significant difference in the level of contamination within the three locations of the study area. This could be due to the fact that vendor's perception and awareness about food safety was similar irrespective of location.

The survey has given a broad picture of the prevalence of relevant bacterial organisms contaminating foods such as Garri, rice, yam, fufu and beans in Calabar metropolis. It however, did not go a step forward to shed more light on where food borne illnesses may arise. Getting detailed information information will cost a lot. It is clear that the major pathogens, coliform bacteria, Bacillus spp, S. aureus arose either in the primary production or in final production and it is important to deal with them at the source.As Urban population increases and the consumption of street vended foods increases, then there is the urgent need for a readily available and effective intervention.Closed observations through inspection of food vending areas and utensils, methods of food storage and other vending facilities confirmed that hygiene was highly compromised among the food vendors. 


\section{References}

[1]. Van Ermengen, E. (1998). Ueber einen anaroben Bacillus und seine Beziehungen Zum Botullsmus. Z_Hyg. Infektlo.26, 1-86

[2]. Dawson, 0. R \& Carneth, L.M. (1991). Human Nutrition in the Developing World. FAO publication and papers relating to street Foods.

[3]. Weber, J.T., Hibbs, R.G., Darwish, A., Mishu, B., Corwin, A.L., Rakha, C.L, Hatheway, S.E., Sharka'.vy, S.A. \& El Rakha, M.F.S (1993). A massive outbreak of type E. boutilism associated with traditional salted fish in cairo. J_infect_Dis,, 167451 - 454

[4]. Motermans, S. \& Teunio, P. (1996). Quantitative Risk Analysis and production of microbiologically safe food: An Introduction. In MicrobioL 30, 3-7

[5]. Notermans, V. D., Rodhouse, M.J \& Gilbert, R. J. (1990) DNA probes for detection of enterotoxigenic Clostridium perfringens strains isolated from outbreaks of food poisoning. ) DNA probes for detection of enterotoxigenic Clostridium perfringens strains isolated from outbreaks of food poisoning. J,_chid.MicrobjoL, 28, 131

[6]. Reiser, R.i., Conaway, D. \& Bergdoll, M.S. (1974). Detection of Staphylucoccal enterotoxin in food, Appl.Microbial., 27,83 - 85

[7]. Fadio, W.IM. \& Jackson, H. (1989). Effect of tempering on the heat resistance of Listeria monocytogenes. Lett. Appl. Microbiol.. 9 , $157-160$

[8]. John P. Harley., Lansing. M Prescott (1993). Laboratory Exercises in microbiology, $2^{\text {nd }}$ edi, 1CL 174 - 177

[9]. Lenne, E.H., Balow, A., Hansler, W.J. et al (1980): Manual of Clinical Microbiology, $3^{\text {rd }}$ Ed. Pp 399 - 416, Wasthintong DC Am. Soc Microbiol.

[10]. Brown, C. (1993). Food Microbiology (2 $2^{\text {nd }}$ ed). London: Me Graw Hill.

[11]. World Health Organization (1992). The role of molluscide in schistosomiasis control. WHCLSchist 92107 -134

[12]. Sobel, J., Mahon B, Mendoza, C., Passaro, D., Cano F., Biier, K., Racioppi, F., Hutwagner, L. \& Mintz, E.(1998). Reduction of feacal termination of street system water purification and storage, hand washing, and beverage storage. Journal_of_Water_Syste.m, 48, 417 - 487

[13]. Quick heka,L., Mosupye, C. \& Von Holy, F. M. (2001) Microbiological survey of street vended Salad and gravy in Johannesburg City. South Africa. J. Food Microbio., 12 (2)m 127 - 131. 